\title{
Wistar Strain Rats as the Model for IgE Antibody Experiments
}

\author{
Takashi Hirano, Nobuhide Kawasaki, Hideki Miyataka, ${ }^{*}$ and Toshio SatoH ${ }^{1)}$ \\ Department of Bio-organic Medicinal Chemistry, Faculty of Pharmaceutical Sciences, Tokushima Bunri University, \\ Yamashiro-cho, Tokushima 770-8514, Japan. Received November 20, 2000; accepted April 14, 2001
}

\begin{abstract}
The amount of plasma IgE antibody formed and its change over time were investigated by enzyme-linked immunosorbent assay (ELISA) in male and female Sprague-Dawley (SD), Donryu, and Wistar strain rats. IgE antibody formation was initiated by injecting a mixture of 2,4-dinitrophenylated ascaris extract (DNP-As) as antigen and killed Bordetella pertussis as adjuvant into the paws of the animals. The amount of IgE antibody formed was low on day 10 in both male and female SD $(40-80 \mathrm{ng} / \mathrm{ml})$ and Donryu $(20-40 \mathrm{ng} / \mathrm{ml})$ strain rats, and an increase in the amount was observed on day 20 . The peak value of IgE antibody was observed day 10 in Wistar strain rats and was 130 and $200 \mathrm{ng} / \mathrm{ml}$ in the male and female rats, respectively. These results suggest that Wistar strain rats produce the most IgE antibody when DNP-As is used as antigen and they can serve as a model for allergic diseases.
\end{abstract}

Key words allergy; IgE; DNP-As; Bordetella pertussis; ELISA; Wistar rat

In recent years, an increase has been reported globally in the number of cases of allergic disease. Japan is no exception, and allergic diseases including cedar pollenosis, atopic diseases, and extrinsic asthma have raised grave social concern. ${ }^{2)}$ These allergic symptoms are generally classified as the type I allergy and well-known immediate-type reactions. They are also known to be caused by the release of mediator from target cells such as mast cells and basophils following exposure to an antigen. When an antigen enters the body, it is phagocytosed by macrophages, which then present it to $\mathrm{T}$ cells. Differentiated (proliferated) $\mathrm{T}$ cells present the antigen to B cells. After differentiation to antibody-forming cells by the action of cytokines such as interleukin (IL)-4, B cells produce IgE antibody. ${ }^{3)}$ An increase in plasma IgE level is observed in about $80 \%$ of patients with atopic dermatitis and this is closely related to their long-term serious symptoms. ${ }^{4,5)}$ We attempted to prepare rats with high IgE as a model of patients with allergic diseases. Rats were activated using 2,4dinitrophenylated ascaris extract (DNP-As) as antigen and were immunized with killed Bordetella pertussis as adjuvant, which is reported to enhance $\operatorname{IgE}$ antibody formation in rats and mice. ${ }^{6-8)}$ The amount of IgE antibody formed and its change over time were then studied in the rats.

\section{MATERIALS AND METHODS}

Animals Six-week-old male and female, Sprague-Dawley (SD), Donryu, and Wistar strain rats were kindly supplied by Japan SLC Inc. The animals were used in the experiments after preliminary feeding for one week.

Reagents DNP-As and killed B. pertussis were purchased from LSL Co., Ltd., and Chiba Serum Research Laboratory, respectively. Morinaga Institute of Biological Sciences kindly donated enzyme-linked immunosorbent assay (ELISA) kits (Morinaga Rat IgE ELISA Kit).

Immunization Immunization of rats was performed with reference to the method of Matsuura et al. ${ }^{9)} \mathrm{DNP}-\mathrm{As}$ (1 mg per animal) was dissolved in physiological saline $0.1 \mathrm{ml}$ and the solution was mixed with killed $B$. pertussis $0.5 \mathrm{ml}$ of containing $10^{10}$ cells. The mixture was subcutaneously injected in the paws of each rat for early immunization. Five days after early immunization, a solution of DNP-
As $0.5 \mathrm{mg}$ in physiological saline $0.25 \mathrm{ml}$ was injected into the back muscle of each rat to produce additional immunization.

Blood Sampling and Measurement Blood was drawn from the jugular vein of each rat $0,5,10,20$, and $25 \mathrm{~d}$ after additional immunization. The day of additional immunization was taken as day 0 . The blood was centrifuged at $4{ }^{\circ} \mathrm{C}$ for $10 \mathrm{~min}$ at $700 \times \mathbf{g}$ and the plasma obtained was used as the sample. The plasma was frozen at $-20^{\circ} \mathrm{C}$ and stored until the time of $\operatorname{IgE}$ determination. The amount of $\operatorname{IgE}$ was determined by the EIA sandwich method using ELISA. The sample was placed in a plate coated with solid phase-bound anti-rat IgE monoclonal antibody and the plate was allowed to stand at room temperature for $4 \mathrm{~h}$, during which the antibody formed a complex with rat IgE. After washing each well, enzyme-labeled sheep anti-rat IgE antibody was added to the well to cause complex formation with rat $\operatorname{IgE}$ while allowing it to stand for $2 \mathrm{~h}$ at room temperature. After washing and addition of an enzyme substrate solution (TMB solution), the well was allowed to stand in darkness for $30 \mathrm{~min}$ at room temperature and then the reaction was stopped with $1 \mathrm{~N}$ $\mathrm{H}_{2} \mathrm{SO}_{4}$. The absorbance was measured with a microplate photometer (BIO-RAD 550) at $450 \mathrm{~nm}$.

\section{RESULTS}

The change over time in the amount of IgE was investigated with the day of DNP-As administration for additional immunization taken as the day 0 . The IgE level began to increase on day 5 and was $80 \mathrm{ng} / \mathrm{ml}$ on day 10 in female SD strain rats (Fig. 1). It then decreased but exhibited a rise on day 20. Male SD rats had an IgE level of $40 \mathrm{ng} / \mathrm{ml}$ on day 10 , after which the level gradually decreased. While the $\operatorname{IgE}$ level showed an increase on day 20 in both male and female Donryu rats as in SD rats, IgE production was generally low in the former strain rats, as shown in Fig. 2. No IgE concentration increase was observed on day 5 in Wistar strain rats, unlike rats of the other strains (Fig. 3). Instead, the IgE on day 10 was 140 and $200 \mathrm{ng} / \mathrm{ml}$ in male and female rats, respectively, and then decreased rapidly.

Based on the above results, reinvestigation and reconfirmation of IgE formation were conducted in Wistar rats. The 


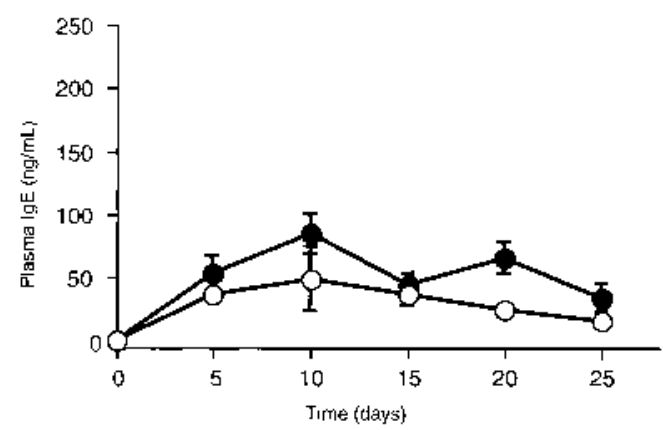

Fig. 1. Time Course of Change in Plasma IgE Level in SD Rats Immunized with Killed $B$. pertussis/DNP-As

○, SD male; $\bullet$ SD female. Results are expressed as the mean \pm S.E. of 4 rats.

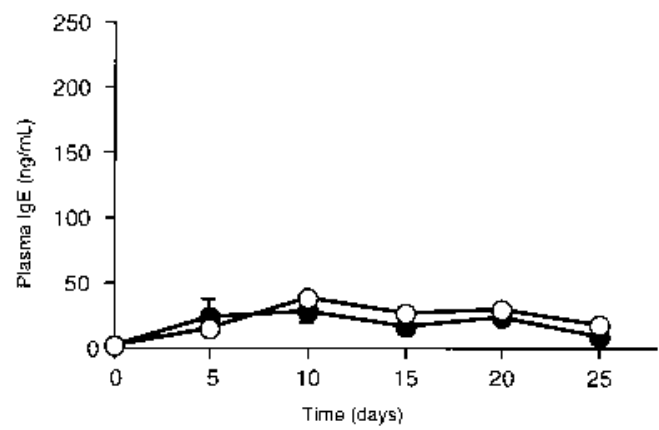

Fig. 2. Time Course of Change in Plasma IgE Level in Donryu Rats Immunized with Killed $B$. pertussis/DNP-As

○, Donryu male; $\bullet$, Donryu female. Results are expressed as the mean \pm S.E. of 4 rats.

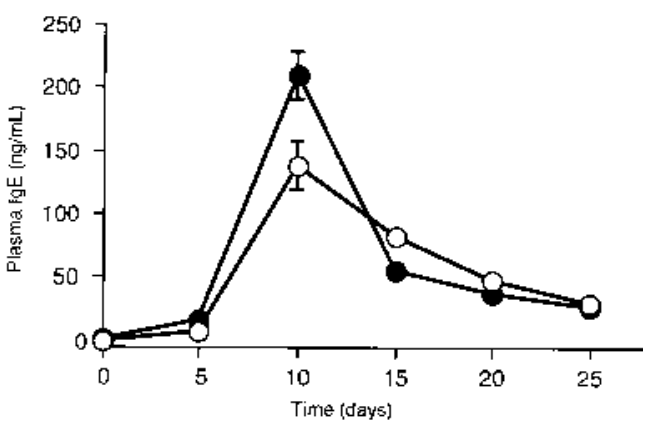

Fig. 3. Time Course of Change in Plasma IgE Level in Wistar Rats Immunized with Killed B. pertussis/DNP-As$$
\text { rats. }
$$
rats.

plasma IgE level exhibited no rise on day 5 and then rapidly increased to 115 and $174 \mathrm{ng} / \mathrm{ml}$ in male and female rats, respectively, on day 10 , after which it rapidly declined.

\section{DISCUSSION}

The present study showed a remarkable effect of animal strain on immunization-induced $\operatorname{IgE}$ formation in rats. $\operatorname{IgE}$ formation was particularly high and changed rapidly over time in Wistar rats. This suggests the usefulness of Wistar rats as an animal model for allergic diseae. It is generally accepted that Brown Norway (BN) rats are a useful model for bronchial asthma, a typical type I allergy. ${ }^{10)} \mathrm{BN}$ rats have many features suitable for an animal model for bronchial asthma since they form IgE antibody ${ }^{11)}$ and develop antigeninduced bronchoconstriction, immediate- and retarded-type reaction, ${ }^{12,13)}$ eosinophilic bronchitis, ${ }^{14)}$ and Th2 cytokine. ${ }^{15)}$ Our present study showed that Wistar rats exhibit a peak IgE level $10 \mathrm{~d}$ after sensitization using DNP-As as antigen and $B$. pertussis as adjuvant and produce a high level of IgE, as frequently observed in allergic disease. Consequently, female Wistar rats are suggested to be useful as a control animal group in the evaluation of such compounds as suplatast tosilate (IPD-1151T) $)^{9,16-19)}$ that suppress $\operatorname{IgE}$ formation and Th2-type cytokines. Thus our results indicate that animal strain affects experimental results even when the identical method of disease model preparation is used. The most appropriate rat strain should be selected to evaluate the effectiveness of drugs in animal models.

Acknowledgements We donating thank Morinaga Institute of Biological Sciences and Japan SLC Inc. for kindly donating ELISA kits and rats, respectively.

\section{REFERENCES}

1) Deceased.

2) Nakagomi T., Itaya H., Tominaga T., Yamaki M., Hisamatsu S., Nakagomi O., Lancet, 343, 121-122 (1994).

3) Sutton B. J., Gould H. J., Nature (London), 366, $421-428$ (1993).

4) Hoffman D. R., Yamamoto F. Y., Geller B., Haddad Z., J. Allergy Clin. Immunol., 55, 256-267 (1975).

5) Wittig H. J., Belloit J. B., Fillippi I. D., Royal G., J. Allergy Clin. Immunol., 66, 305-313 (1980).

6) Clausen C. R., Monz J., Bergman R. K., J. Immunol., 103, 768-777 (1969).

7) Tada T., Okumura K., J. Immunol., 106, 1002-1011 (1971).

8) Mizushima Y., Mori M., Ogita T., Int. Arch. Allergy Appl. Immunol., 58, 426-429 (1979).

9) Matsuura N., Yanagihara Y., Mori H., Nagai H., Koda A., Jpn. Pharmacol. Ther., 22, 1369-1383 (1994).

10) Eidelman D. H., Bellofiore S., Martin J. G., Am. Rev. Resir. Dis., 137, 1033-1037 (1988).

11) Waserman S., Olivenstein R., Renzi P., Xu L. J., Martin J. G., J. Allergy Clin. Immunol., 90, 661-669 (1992).

12) Cockcroft D. W., Ruffin R. E., Dolovich J., Hargreave F. E., Clin. Allergy, 7, 503-513 (1977).

13) O’Byrne P. M., Dolovich J., Hargreave F. E., Am. Rev. Respir. Dis., 136, 740-751 (1987).

14) Watanabe A., Mishima H., Renzi P. M., Xu L. J., Hamid Q., Martin J. G., J. Clin. Invest., 96, 1303-1310 (1995).

15) Robinson D., Hamid Q., Ying S., Tsicopoulous A., Barkans J., Bentley A. M., Corrigan C., Durham S. R., Kay A. B., N. Engl. J. Med., 326, 298-304 (1992).

16) Hanashiro K., Tamaki N., Koga T., Nakamura M., Kinjho K., Kosugi T., Int. J. Tiss. React., 65, 163-169 (1997).

17) Yanagihara Y., Kiniwa M., Ikizawa K., Yamaya H., Shida T., Matsuura N., Koda A., Jpn. J. Pharmacol., 61, 23-30 (1993).

18) Yanagihara Y., Kiniwa M., Ikizawa K., Shida T., Matsuura N., Koda A., Jpn. J. Pharmacol., 61, 31-39 (1993).

19) Koda A., Yanagihara Y., Matsuura N., Therapy, 34, 369-378 (1991). 